\title{
KONTRIBUSI PERGURUAN TINGGI DALAM MENUMBUHKAN SEMANGAT BELA NEGARA DI KALANGAN PELAJAR SMPN 02 BELITANG HILIR
}

Agnesia Hartini, Fusnika

STKIP Persada Khatulistiwa Sintang

Agnesiahartini@yahoo.com

\begin{abstract}
The issue of the integrity and sovereignty of the state as a form of national resilience is a central discourse that becomes a strategic study in every country. Appreciating the birth of a country is highly needed, especially when the birth of a country was obtained through a long road with a bitter struggle sacrificing the soul and body as a stakes. Thus, it was reasonable that the various steps were taken for the sake of the integrity and sovereignty of a State. State defensewas the effort of every citizen of the Republic of Indonesia against threats, both from outside and from inside the country. The definition provided an understanding that state defensewas an obligation for every Indonesian citizen.The counseling was done at Empajak village which was located in Kecamatan Belitang Hilir Kabupaten Sekadau. The subjects involved in this research were the students at SMPN 02 Sekadau District who were counse ledregarding the importance of the state defense spirit. They were involved as participants who became the object of counseling activities. The problems found were the lack of awareness of students' patriotism towards their own country. Through this counseling activity, it was expected that this activity could contribute to promote students's state defense spirit. College had the ability and authority to directly apply science and technology into society's life.

Keywords: College's Contribution, State Defense Spirit, Students
\end{abstract}

\begin{abstract}
Abstrak: Isu mengenai keutuhan dan kedaulatan negara sebagai bentuk ketahanan nasional merupakan wacana sentral yang menjadi kajian strategis di setiap negara. Eksistensi suatu negara menjadi harga mahal yang harus dipertahankan sebagai bentuk penghargaan atas lahirnya suatu negara, terlebih ketika lahirnya suatu negara diperoleh melalui jalan panjang dengan perjuangan pahit yang tak pelak harus mengorbankan jiwa dan raga sebagai taruhannya. Sehingga, sangat beralasan jika berbagai langkah ditempuh demi keutuhan dan kedaulatan suatu Negara. Bela negara adalah upaya setiap warga negara Republik Indonesia terhadap ancaman, baik dari luar maupun dari dalam negeri. Definisi tersebut memberikan pemahaman bahwa upaya bela negara merupakan kewajiban bagi setiap warga negara Indonesia. Lokasi Pengabdian di Desa Empajak merupakan sebuah desa yang terletak di Kecamatan Belitang Hilir Kabupaten Sekadau. Mitra yang terlibat pada pengabdian ini adalah para pelajar di SMPN 02 Kabupaten Sekadau yang mengalami sasaran dalam penyuluhan pentingnya semangat Bela Negara. Keterlibatan mereka adalah sebagai peserta yang menjadi objek sasaran dari kegiatan Penyuluhan. Permasalahan yang ditemukan antara lain; kurangnya kesadaran para pelajar dalam menumbuhkan kecintaan terhadap tanah air. Melalui kegiatan penyuluhan dapat memberikan kontribusi untuk menumbuhkan semangat Bela Negara dikalangan pelajar, Perguruan Tinggi memiliki kemampuan dan kewenangan untuk menerapkan langsung ilmu pengetahuan dan teknologi tersebut dalam kehidupan masyarakat.
\end{abstract}

Kata kunci: Kontribusi Perguruan Tinggi, Semangat Bela Negara, Kalangan Pelajar 


\section{A. PENDAHULUAN}

Isu mengenai keutuhan dan kedaulatan negara sebagai bentuk ketahanan nasional merupakan wacana sentral yang menjadi kajian strategis di setiap negara. Eksistensi suatu negara menjadi harga mahal yang harus dipertahankan sebagai bentuk penghargaan atas lahirnya suatu negara, terlebih ketika lahirnya suatu negara diperoleh melalui jalan panjang dengan perjuangan pahit yang tak pelak harus mengorbankan jiwa dan raga sebagai taruhannya. Sehingga, sangat beralasan jika berbagai langkah ditempuh demi keutuhan dan kedaulatan suatu negara.

Begitu getirnya perjuangan dalam meraih kemerdekaan, menjadikan keutuhan dan kedaulatan sebagai kondisi yang harus selalu dijaga dan dilestarikan sebagai wujud nyata dalam mengisi dan mempertahankan

kemerdekaan.

Berbagai langkah strategis ditempuh sebagai bentuk pertahanan untuk mewujudkan ketahanan nasional. Salah satu langkah yang dimaksud adalah upaya bela negara. Menurut Winarno (2009:182) "Bela negara adalah upaya setiap warga negara Republik Indonesia terhadap ancaman, baik dari luar maupun dari dalam negeri".

Definisi tersebut memberikan pemahaman bahwa upaya bela negara merupakan kewajiban bagi setiap warga negara Indonesia, bahkan juga sebagai hak yang harus ditunaikan warga terhadap negara. Hak dan kewajiban tersebut merupakan wujud kecintaan terhadap bangsa dan negara Indonesia (nasionalisme) yang harus selalu ditumbuh kembangkan.

Hak dan kewajiban bela negara seperti halnya yang disebutkan dalam definisi bela negara tersebut dengan tegas dimuat dalam Undang-Undang Dasar Negara Republik Indonesia (UUD NRI) Tahun 1945 pada Pasal 27 ayat (3) perubahan kedua, yang berbunyi "Setiap warga negara berhak dan wajib ikut serta dalam upaya pembelaan negara". Ketentuan mengenai upaya bela negara tersebut dijelaskan lebih lanjut dalam Undang-Undang (UU) Nomor 3 Tahun 2002 tentang Pertahanan Negara. Pada Pasal 9 ayat (1) UU No. 3 Tahun 2002 disebutkan bahwa "Setiap warga negara berhak dan wajib ikut serta dalam upaya bela negara yang diwujudkan dalam penyelenggaraan pertahanan negara". Urgensi dari dua pasal tersebut menimbulkan konsekuensi bahwa setiap warga negara baik pemerintah maupun masyarakat memiliki hak dan kewajiban untuk turut serta dalam upaya bela negara. 
Seperti yang dituangkan dalam penjelasan UU No. 3 Tahun 2002 bahwa "Upaya bela negara adalah sikap dan perilaku warga negara yang dijiwai oleh kecintaannya kepada Negara Kesatuan Republik Indonesia (NKRI) yang berdasarkan Pancasila dan UUD 1945 dalam menjamin kelangsungan hidup bangsa dan negara". Oleh sebab itu, setiap warga negara wajib turut serta dalam setiap usaha pembelaan negara sesuai dengan kemampuan dan profesinya masing-masing sebagai perwujudan dari cintah tanah air (nasionalisme).

Pada dasarnya, upaya bela negara secara non-fisik memiliki fungsi yang sama pentingnya dengan bela negara secara fisik. Karena secara kuantitas, jumlah masyarakat sipil yang tidak ikut tergabung sebagai anggota TNI dan unsur kemasyarakatan yang memperoleh pendidikan dasar kemiliteran lebih banyak jika dibandingkan dengan jumlah anggota TNI dan unsur kemasyarakatan yang memperoleh pendidikan dasar kemiliteran itu sendiri. Oleh sebab itu, perlu adanya penanaman kesadaran diri masyarakat sebagai bangsa dan negara Indonesia agar dapat memahami dan menghayati pentingnya keikutsertaan dalam upaya bela negara.
Dengan demikian, melalui bela negara secara non-fisik ini semua elemen mayarakat dapat melibatkan diri dan mengambil bagian dalam upaya bela negara. Berdasarkan penjelasan tersebut dapat dipahami bahwa keikutsertaan bela negara tidak hanya dilakukan oleh pemerintah melainkan juga masyarakat sipil, tidak hanya oleh golongan tua melainkan juga para pemuda, tidak hanya oleh laki-laki, melainkan juga perempuan. Karena, seperti yang sudah dijelaskan bahwa upaya bela negara tidak hanya upaya memanggul senjata, adapun bagi pelajar bentuk bela negara adalah mematuhi semua tata tertib sekolah dengan tertib, mengikuti kegiatan belajar dan mengajar dan upacara dengan baik, menjaga nama baik sekolah, baik itu di dalam sekolah maupun di luar sekolah.

Sebagai agen perubahan, perguruan tinggi sekurang-kurangnya memiliki tiga peran, yaitu selaku sumber ilmu pengetahuan, kontributor, serta implementator. Sebagai sumber ilmu pengetahuan, di lingkungan Perguruan Tinggi terdapat manusia terdidik yang memiliki kemampuan akademik untuk memperkaya khasanah ilmu pengetahuan dan teknologi serta mengembangkan dan 
menyebarluaskan ilmu pengetahuan dan teknologi tersebut. Peran sebagai kontributor, artinya perguruan tinggi menyumbangkan kemampuannya itu untuk meningkatkan kesejahteraan hidup masyarakat. Terakhir, peran selaku implementator, Perguruan Tinggi memiliki kemampuan dan kewenangan untuk menerapkan langsung ilmu pengetahuan dan teknologi tersebut dalam kehidupan masyarakat.

Berdasarkan pemaparan yang sudah diuraikan diatas, maka salah satu solusi yang dapat diberikan adalah memberikan Penyuluhan bagi kalangan pelajar yang berjudul "Menumbuhkan Semangat Bela Negara di kalangan pelajar SMPN 02 Belitang Hilir".

\section{B. METODE}

\section{Dalam}

pelaksanaannya program ini direncanakan dilaksanakan melalui 2 (dua) langkah atau tahapan kegiatan sebagai berikut:

1) Tahap Perencanaan

Adalah tahap pemantapan rencana pelaksanaan kegiatan penyuluhan, pada tahapan ini tim dan peserta menyepakati teknis dan tempat pelaksanaan penyuluhan termasuk mengenai kepastian waktu dan lamanya kegiatan yang dimaksud.

2) Tahap Pelaksanaan

Pada tahapan ini dilaksanakannya kegiatan penyuluhan:

Meningkatkan keasadaran para pelajar untuk menjaga dan melestarikan lingkungan, meningkatkan kesadaran para pelajar menumbuhkan kecintaan terhadap tanah air, meningkatkan kesadaran para pelajar memperlakukan Lambang Negara, Bendera Kebangsaan dan lagu Kebangsaan Indonesia Raya secara benar, meningkatkan kesadaran para pelajar untuk urut membina \& melestarikan kebudayaan daerah sebagai bagian dari kebudayaan Nasional. Praktik penyuluhan ini dilakukan 1 kali pertemuan dengan waktu satu bulan. pada kearifan lokal masyarakat setempat.

\section{PEMBAHASAN DAN HASIL}

\section{Pembahasam}

\section{A. Pengertian Bela Negara}


Bela negara adalah sikap, tekad dan juga perilaku warga negara yang dilakukan secara menyeluruh, teratur serta terpadu dan juga dijiwai oleh kecintaan terhadap Negara Kesatuan Republik Indonesia (NKRI) berdasarkan Pancasila dan UUD 1945 untuk menjamin kelangsungan hidup berbangsa dan bernegara.Dasar hukum mengenai bela negara terdapat dalam isi UUD 1945, yakni:

a. Pasal 27 ayat (3) yang menyatakan bahwa semua warga negara berhak dan wajib ikut serta dalam upaya pembelaan negara.

b. Pasal 30 ayat (1) yang menyatakan bahwa tiap-tiap warga negara berhak dan wajib ikut serta dalam usaha pertahanan dan keamanan negara.

\section{B. Fungsi Dan Tujuan Bela Negara}

Bela negara memiliki fungsi dan tujuan sebagai berikut:

a. Tujuan Bela Negara

Membangun semangat Bela Negara pada pemuda merupakan sesuatu yang penting dan tidak bisa dianggap suatu hal yang sepele, karena pemuda merupakan generasi penerus bangsa yang tidak dapat didisparitaskan dari sejarah bangsa ini. Kendatipun demikian, semangat bela negara ini jangan pula ditafsir hanya berhubungan dengan angkat senjata melawan musuh dari negara luar belaka, melainkan harus lebih luas memandangnya.

Sehingga dalam pengejawantahannya, pemuda lebih kreatif mengimplementasikan arti bela negara ini dalam kehidupannya tanpa menghilangkan hakekat bela negara itu sendiri. Sebuah keharusan bagi pemuda untuk ikut bersama bertanggung jawab mengemban amanat penting ini.

Apabila pemuda sudah tidak terpatri dalam dirinya akan semangat mengenai bela negara, maka ini merupakan ancaman besar bagi kehidupan berbangsa dan bernegara, bisa jadi suatu saat mengakibatkan bangsa ini akan berada ke dalam kondisi yang sangat parah bahkan jauh terpuruk dari bangsa-bangsa lain yang telah mempersiapkan diri dari gangguan bangsa lain. Oleh sebab semangat bela negara memiliki tujuan sebagai berikut:

\footnotetext{
$\checkmark$ Menjalankan nilai-nilai Pancasila dan UUD 1945.

$\checkmark$ Menjaga identitas dan integritas bangsa dan negara.

$\checkmark$ Melestarikan budaya.
} 
$\checkmark \quad$ Mempertahankan kelangsungan hidup bangsa dan juga negara.

$\checkmark$ Berbuat yang terbaik bagi bangsa dan juga negara.

b. Fungsi Bela Negara

$\checkmark \quad$ Merupakan kewajiban setiap warga negara.

$\checkmark \quad$ Mempertahankan Negara dari berbagai ancaman.

$\checkmark$ Merupakan panggilan sejarah.

$\checkmark \quad$ Menjaga keutuhan wilayah negara.

\section{Manfaat Bela Negara}

Bela negara memiliki beragam manfaat, baik bagi individu masingmasing warga negara ataupun bagi negara itu sendiri. Berikut ialah beberapa contoh manfaat bela negara:

a. Menanamkan rasa kecintaan pada Bangsa dan Patriotisme sesuai dengan kemampuan masing-masing.

b. Membentuk Iman dan Taqwa pada masing-masing Agama.

c. Melatih jiwa kepemimpinan dalam memimpin diri sendiri ataupun kelompok.

d. Menghilangkan sikap negatif, misalnya malas, apatis, boros, egois, dan tidak disiplin. e. Membentuk sikap disiplin akan waktu, aktivitas, dan juga pengaturan kegiatan lain.

f. Membentuk perilaku jujur, tegas, adil, tepat, serta kepedulian antar sesama.

g. Membentuk jiwa kebersamaan serta solidaritas antar sesama rekan seperjuangan.

h. Membentuk mental dan juga fisik yang tangguh.

i. Berbakti pada orang tua, bangsa, dan agama.

j. Melatih kecepatan, ketepatan, ketangkasan individu dalam melaksanakan beragam kegiatan.

\section{HASIL}

\section{A. Hasil Kegiatan}

Kegiatan pengabdian ini dilaksanakan pada tanggal 30 Oktober 2017, dimulai pada pukul 09.00 Wib s/d 11. 30 Wib bertempat di desa Empajak. Kegiatan tersebut dihadiri oleh 67 orang siswa.

\section{Persiapan}

a. Persiapan Tim (Pemateri)

Sebelum terjun kelapangan terlebih dahulu tim secara bersama-sama memantapkan persiapan pelaksanaan kegiatan baik dari segi 
pemahaman materi maupun

pemantapan keterampilan

dalam melakukan simulasi

dalam kegiatan ini.

b. Persiapan

Pelaksanaan

Koordinasi Desa dan Peserta

Demi kelancaran kegiatan

tersebut ketua tim dan anggota

dalam waktu satu bulan

berkoordinasi dengan pihak-

pihak terkait, seperti pihak

kecamatan, pihak desa dan

masyarakat setempat. Dalam

tahap ini tim setelah mendapat

persetujuan mengadakan

kesepakatan tempat, tanggal

dan waktu pelaksanaan.

Pemilihan tempat, tanggal dan

waktu pelaksanaan disesuaikan

dengan kesediaan pihak

sekolah SMPN 02 Belitang

Hilir dan tim penyuluhan.

Kemudian disepakati

pelaksanaan pada hari senin

tanggal 30 Oktober 2017 di

SMPN 02 Belitang Hilir Desa

Empajak.

\section{Pelaksanaan}

Kami tim pelaksana

melaksanakan kegiatan

penyuluhan tentang Kontribusi
Perguruan Tinggi dalam

menumbuhkan Semangat Bela

Negara di kalangan pelajar

SMPN 02 Belitang Hilir, 30

Oktober 2017. Kegiatan ini dijadwalkan pada pukul 09.00 Wib. Penyuluhan tentang Kontribusi Perguruan Tinggi dalam menumbuhkan Semangat Bela Negara di kalangan pelajar SMPN 02 Belitang Hilir dibuka oleh Ibu Herdiana Sulian, selaku kepala Sekolah SMPN 02 Belitang Hilir dan dilanjutkan oleh Tim sebagai tutor dalam kegiatan penyuluhan. Acara dilanjutkan dengan kegiatan penyuluhan yang dilaksanakan terdiri dari 2 sesi:

\section{a. Sesi Penyampaian Materi (Tim Penyuluhan).}

1. Pembukaan: pendahuluan dan pengantar materi oleh tim penyuluh pertama.

2. Penyampaian materi sanksi hukum terhadap pelanggaran bela negara oleh penyuluh kedua.

b. Sesi Tanya Jawab.

1. Pada tahapan ini diberi kesempatan kepada siswa 


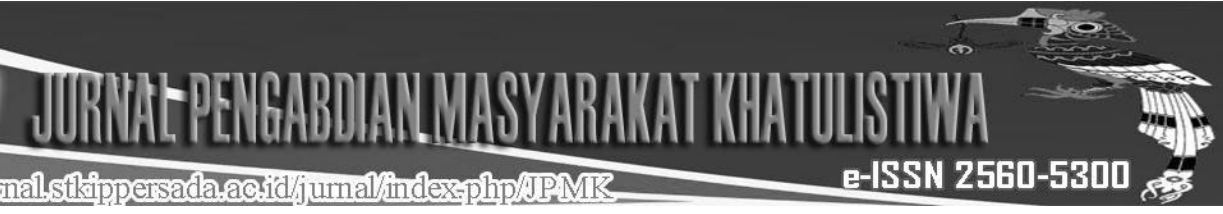

$\begin{array}{lrr}\text { untuk bertanya } & \text { dan } \\ \text { merespon materi } & \text { yang } \\ \text { disampaikan } & \text { oleh } & \text { tim } \\ \text { penyuluh. } & & \end{array}$

2. Pada tahap selanjutnya siswa melaksanakan simulasi tentang bentuk-bentuk bela negara.

\section{c. Evaluasi Hasil Kegiatan}

Dari hasil kegiatan yang telah dilaksanakan terdapat beberapa hal yang menjadi kesimpulan yakni:

1. Peserta antusias mengikuti kegiatan yang terbukti $100 \%$ peserta tetap mengikuti kegiatan sampai selesai.

2. Peserta bisa mempraktekan bentuk bela negara dalam kehidupan sehari-hari.

3. Peserta mampu memberikan contoh-contoh bela negara.

\section{Dokumentasi}

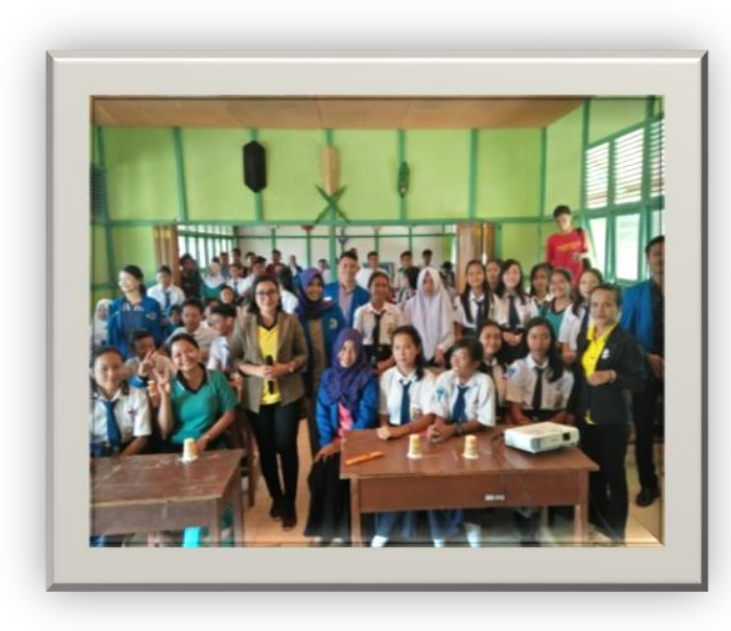

Foto Bersama Tim Pengabdian Dengan Siswa SMPN 02 Belitang Hilir

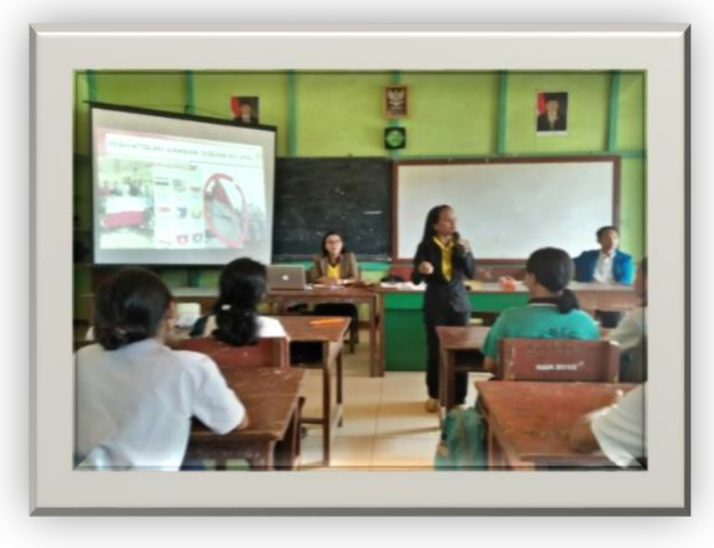

Pemaparan Materi Penyuluhan

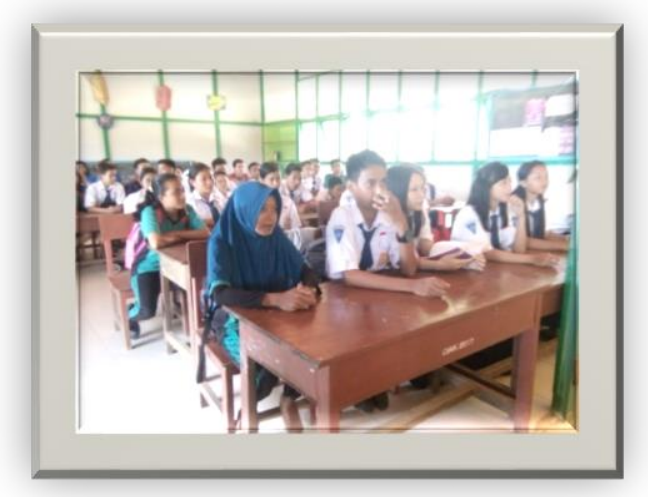

Siswa Menyimak Pemaparan Materi 


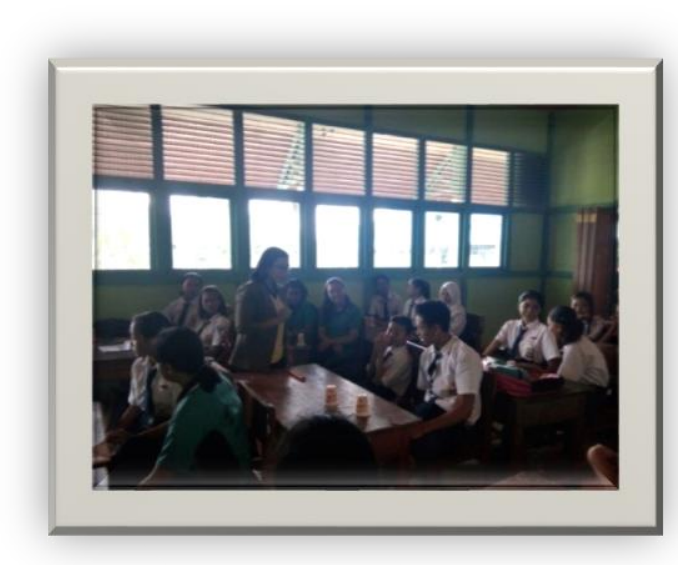

Tanya Jawab Dengan Siswa

\section{SIMPULAN}

Berdasarkan dari hasil pelaksanaan penyuluhan yang telah lakukan, dapat disimpulkan sebagai berikut bahwa Bela negara merupakan sebuah semangat berani berkorban demi tanah air, baik harta bahkan nyawa sekalipun berani dikorbankan demi keutuhan negara kesatuan republik Indonesia.

Bela negara adalah tekad, sikap dan tindakan warganegara yang teratur, menyeluruh, terpadu dan berkelanjutan yang dilandasi oleh kecintaan terhadap tanah air serta kesadraan hidup berbangsa dan bernegara. Terciptanya semangat bela negara di kalangan pelajar SMPN 02 Belitang Hilir dilandasi oleh kecintaan pada tanah air (wilayah nusantara) dan kesadaran berbangsa dan bernegara Indonesia

dengan keyakinan pada pancasila sebagai dasar negara serta berpijak pada Undang-Undang Dasar 1945 sebagai landasan kontitusi negara.

Siswa dapat memberikan contoh nyata tentang semangat bela negara secara konkrit dalam kehidupan sehari-hari. Bentuk kesadaran bela negara di SMPN. 02 sudah mulai membaik terlihat dari keikutsertaan dalam pelaksanaan upacara bendera, menghormati lambang-lambang negara.

\section{DAFTAR PUSTAKA}

Jamli, Edison dkk. 2005 “Kewarganegaraan”. Jakarta: Bumi Akasara

Soemardjan, Selo (1982),

Perubahan Sosial di

Yogyakarta, Yogyakarta :

Gajah Mada University

Press.

Satiman, Sudewo. 2003 "Dengan

Semangat Berkobar;

Nasionalisme dan Gerakan

Pemuda di Indonesia”. Jakarta:

Hasta Mitra

Undang-Undang Dasar 1945 
Undang-Undang Nomor 3 Tahun

Negara.

2002 tentang Pertahanan 